\title{
Further Investigations into Bacterial and Algal Populations of Caves in South Wales
}

\author{
By M. Ann Mason Wildiams ${ }^{1}$ )
}

In 1958 a paper was published which outlined microbial populations found in air, soil and water of caves in South Wales, Great Britain (Mason-Williams and Benson-Evans, 1958). From those results it was obvious that the field covered in this initial paper was too wide for further and more detailed study. These subsequent investigations have been concerned only with aspects of the microbial floras of soils and waters of caves. The aerial floras form an absorbing study particularly with regard to the distribution of spores in relation to the draughts within the cave system, but this study is unfortunately very time-consuming and has had to be omitted from the work undertaken by the author.

The earlier work made it obvious that investigations into the physical and chemical features of the cave environment were necessary if a detailed and integrated picture of the microbial ecology of caves was to be obtained. Thus this report on the present state of knowledge of the microbial populations of caves in South Wales falls into two parts:

1. Environmental factors and methods used in measuring them.

2. Species of bacteria and algae found in soils and waters.

No attempt is made here to assess the roles of the various bacteria and algae as a paper considering their ecological importance has been published recently (Mason-Williams, 1965).

\section{Environmental Factors}

For measuring the various physical and chemical factors of the cave environment the following are the principal source references: Cullingford (1960), Geiger (1959), Iwatsuki and Ueno (1959), Mackereth (1963), Trombe (1952), Vandel (1964).

1) Department of Microbiology, University College, Cardiff, U. K. 
The majority of these references is concerned, however, either with the cave as a habitat for animals of macroscopic size, or with variations in physical conditions which could affect the precipitation or resolution of calcium carbonate. There is very little information available concerning minor variations in climate in different areas within a particular cave system. In many cases the reason for this has been the lack of portable instruments sufficiently accurate to make taking such measurements of any scientific value. Fortunately, instruments for physical measurements are becoming more readily available. It is now possible to obtain measurements of $\mathrm{pH}$, temperature and humidity within caves with a reasonable degree of accuracy under strictly reproducible conditions.

The instruments used for the measurements recorded here were:

$p H$. A battery operated portable $\mathrm{pH}$ meter (Analytical Instruments) which gives direct readings of $\mathrm{pH}$ to an accuracy of 0.01 units.

Humidity. A battery operated portable hygrometer (Shaws) which measures the percentage saturation of the air. This hygrometer can be fitted with probes of varying types for the measurement of the moisture content of air or soil. Once calibrated the accuracy of this instrument is high even when measuring humidities greater than $80 \%$.

Temperature. No portable instrument was available of any greater accuracy than a $-10^{\circ}$ to $50^{\circ} \mathrm{C}$. mercury thermometer. This could be read to an accuracy of $\pm 1 / 2{ }^{\circ} \mathrm{C}$.

\section{Table 1}

Some physical data from the cave system, Ogof Ffynnon Ddu.

\begin{tabular}{lccccc}
\hline \multicolumn{1}{c}{ Site } & $\begin{array}{c}\text { Distance from } \\
\text { nearest entrance } \\
\text { ft. }\end{array}$ & $\begin{array}{c}\text { Humidity } \\
\%\end{array}$ & $\begin{array}{c}\text { Temperature } \\
\text { air } \\
{ }^{\circ} \mathrm{C} \text { C. }\end{array}$ & $\begin{array}{c}\text { water } \\
{ }^{\circ} \mathrm{CH} \text {. }\end{array}$ & water \\
\hline 1. Entrance Passage & 130 & 85 & 10 & 7 & 7.8 \\
2. The Cathedral & 220 & 76 & 6.8 & 8.8 & 7.8 \\
3. The Junction & 800 & 83 & 8 & 9 & 7.8 \\
4. Lower Column Passage & 900 & 82 & 8.5 & 9.0 & 7.4 \\
5. Upper Column Passage & 1,000 & 81.5 & 9 & 9.2 & 7.8 \\
6. Candlestick pool & 1,000 & 81 & 9.8 & 8.7 & 8 \\
7. Loopways & 700 & 96 & 7.9 & 8.6 & 7.6
\end{tabular}

These readings illustrate well the range of variations in climates to be found in a particular cave system. For each site the value quoted is the average of a number of readings taken over a period of a few weeks. These readings are representative of those obtained in the 
spring months although apart from sites 1 and 2 , seasonal variations in this particular system are not well-marked.

In the cave environment various chemical factors can be measured and when considering the microbial populations one of the most important of these is the content of organic material to be found in water forming pools and streams. Table 2 gives some results of measurements of oxidisable organic matter as measured by the method given by Mackereth (1963) which is a comparative method measuring the amount of potassium permanganate consumed in oxidising organic matter under standard conditions.

\section{Table 2}

Organic oxygen demand as shown by the oxidation of acid permanganate (Mackereth, 1963). The results are expressed in milligrams of oxygen absorbed per litre of water

\begin{tabular}{lccc}
\hline \multicolumn{1}{c}{ Site } & Minimum & Maximum \\
\hline 1. Entrance Passage & 0.14 & 0.44 & (not subject to exterior \\
2. Cathedral & 0.35 & 0.35 & influences) \\
& & & " \\
3. Upper Column Passage & 0.17 & 0.23 & $"$, \\
4. Candlestick & 0.15 & 0.60 & $"$ \\
5. Loopways & 0.12 & 0.37 &
\end{tabular}

All the samples were taken from pools, none of which are fed from the main stream flowing through the cave.

It will be seen that appreciable quantities of organic matter are present in the waters of this cave, an important fact when populations of micro-organisms are being considered. It will also be seen that the variations in the readings obtained are relatively large. The variations are often greatest in regions of the cave system where outside influences are known to exist. For example, where the overburden of rock is thin and allows considerable surface drainage to percolate into the pools in caves or in regions of the system frequently visited by cavers.

In contrast the physical environment appears to be considerably more stable. Sufficient samples have been taken over a period of time to show that, away from the points at which the cave system is open to outside influences, the physical features of any particular point within the system remain stable for long periods of time and require major disturbances of the system for any significant variations to occur. 


\section{Microbial Populations}

It is convenient to present these under a number of different headings. The identifications of organisms have been made following the authority of Fritsch (1959), Pascher (1925), Breed et al. (1957) and Prévot (1961).

\section{Table 3}

Algal cultures from soil. The organisms listed here were isolated by the methods given in Mason-Williams and Benson-Evans (1958).

The frequency of isolations are shown as follows:

$$
\mathrm{f}=\text { frequent, } \mathrm{s}=\text { occasional, } \mathrm{r}=\text { rare }
$$

\begin{tabular}{|c|c|c|c|c|}
\hline Green algae & & Blue-green algae & & Diatoms \\
\hline Asterococcus superbus & $(\mathrm{r})$ & Anabaena inequalis & (f) & Fragilaria sp. (f) \\
\hline Chlorococcum humicolum & (f) & Aphanocapsa grevillei & (s) & Gomphonema \\
\hline Chlorochytrium viridis & $(\mathrm{r})$ & Chroococcus giganteus & $(\mathrm{r})$ & geminatum \\
\hline Chlorella oulgaris & $(\mathrm{s})$ & Chroococcus turgidus & (f) & Navicula spp. (f) \\
\hline Eremosphaera viridis & $(\mathrm{r})$ & Lyngbya martensiana & $(\mathbf{f})$ & Nitzschia spp. $(\mathrm{r})$ \\
\hline Gloeocystis gigas & (s) & Microcystis aeruginosa & $(\mathrm{r})$ & Synedra \\
\hline Gloeocapsa magma & $(\mathrm{r})$ & Nostoc muscorum & (f) & pulchella \\
\hline Gloeothece linearis & $(\mathrm{s})$ & Phormidium autumnale & (f) & \\
\hline Hormidium flaccidum & $(\mathbf{f})$ & Phormidium tenue & (s) & \\
\hline Oocystis solitaria & $(\mathrm{r})$ & Synechococcus & & \\
\hline Prasiola crispa & (f) & aeruginosa & (f) & \\
\hline Spirogyra sp. & $(\mathrm{r})$ & & & \\
\hline Stichococcus variabilis & $(\mathrm{s})$ & & & \\
\hline Tetraspora gelatinosa & (f) & & & \\
\hline Ulothrix tenuissima & $(\mathrm{r})$ & & & \\
\hline
\end{tabular}

Table 4

Algae associated with soft calcite deposits ${ }^{1}$ ) in caves

Green algae Blue-green algae

Binuclearia tectorum

Chlorococcum humicolum

Geminella mutabilis

Hormidium spp.

Scenedesmus acuminatus

Stichococcus bacillaris
Oscillatoria tenuis

Oscillatoria linaria

Synechococcus elongatus

1) These deposits are of the type known as Moonmilk in Great Britain. The term is not used here as it is ill-defined and has many different meanings. 
Table 5

Bacteria isolated from soils and calcarious deposits

\begin{tabular}{llll}
\hline Autotrophic forms & & Heterotrophic forms & \\
\hline Nitrosomonas europea & (s) & Azotobacter sp. & (s) \\
Nitrococcus europea & (s) & Bacillus cereus & (f) \\
Nitrobacter winogradski & (f) & Bac. cereus var. mycoides & (f) \\
Thiobacillus novellus & (r) & Bac. subtilis & (f) \\
& & Bac. sp. & (f) \\
& Bacterium sp. (Bergey, 1948) & \\
& Citrobacter sp. & (r) \\
& Clostridium pasteurianum & (f) \\
& Cl. tetani & (s) \\
& Cl. spp. & (s) \\
& Cytophaga sp. & (s) \\
& Flavobacterium spp. & (f) \\
& Macromonas bipunctata & (s) \\
& Micrococcus denitrificans & (f) \\
& M. luteus & (f) \\
& M. varians & (s) \\
& Nocardia spp. & (f) \\
& & Pseudomonas calcis & (s) \\
& & Ps. fluorescens & (r) \\
& & Shabdomonas linsbaueri & (f) \\
& & Streptomyces albus & (f)
\end{tabular}

The protozoan Cyrtolophosis mucicola was also found associated with bacteria and algae in soft deposits of calcite.

Table 6

Bacteria isolated in cultures from pools and films of water

\begin{tabular}{|c|c|c|c|}
\hline \multicolumn{2}{|l|}{ Autotrophic } & \multicolumn{2}{|l|}{ Heterotrophic } \\
\hline Nitrosococcus sp. & (s) & Aerobacter aerogenes & $(\mathrm{r})$ \\
\hline Nitrosomonas europaea & (s) & Azotobacter aquatilis & (f) \\
\hline Nitrobacter winogradski & (f) & Bacillus cereus & (f) \\
\hline Thiobacillus novellus & (r) & Bac cereus var. mycoides & (f) \\
\hline & & Bac. sp. & (f) \\
\hline & & Bacterium qualis (Bergey, 1948) & (s) \\
\hline & & Bact. sp. (Bergey, 1948) & (f) \\
\hline & & Caulobacteria $\left.{ }^{1}\right)$ & $(\mathrm{f})$ \\
\hline & & Chlamydobacteria ${ }^{2}$ ) & (f) \\
\hline & & Clostridium pasteurianum & (f) \\
\hline & & Cytophaga sp. & (s) \\
\hline
\end{tabular}

1) Probably members of genus Pasteuria.

2) Probably members of genera Sphaerotilus and Pelonema. 
Table 6 (Continnation)

\begin{tabular}{lll}
\hline Autotrophic & Heterotrophic & \\
\hline & Escherichia coli, irregular & $(\mathrm{r})$ \\
Micrococcus denitrificans & (f) \\
& Micrococcus spp. $\left.{ }^{1}\right)$ & (f) \\
Nocardia sp. & (s) \\
Streptomyces spp. & (s)
\end{tabular}

Table 7

Other micro-organisms from films of water

\begin{tabular}{ll}
\hline Diatoms & Zoo-plankton \\
\hline Navicula sp. & Ostracods \\
Pinnularia sp. & Several species of flagellated \\
& protozoa
\end{tabular}

\section{SUMMARY}

Some physical data collected over a period of a year in seven locations of the Ogof Ffynnon Ddu. cave system in South Wales are reported, including humidity, air and water temperature, $\mathrm{pH}$ of the water, as well as the organic oxygen demand of the water. It is shown that seasonal variations in the physical constant in this particular cave system are not well marked. Algae and bacteria were isolated from the soil samples and from calcareous deposits. A total of 30 algal species, of which 13 belong to the Cyanophyta, 22 to the Chlorophyta, and 7 to the Chrysophyta-Baccilariophyceae were found. Thirty-eight heterotrophic and 7 autotrophic bacteria were isolated. The thin films on water surfaces, besides diatoms, contained several flagellates and some ostracods, while some protozoa were found associated with the bacteria and algae in the soft calcite deposits.

\section{ZUSAMMENFASSUNG}

Einige physikalische Daten, die im Laufe eines Jahres von 7 Fundstellen des Ogof-Ffynnon-Ddu.- Höhlensystems in Süd-Wales gesammelt wurden, geben nicht nur die Feuchtigkeit, Luft- und Wassertemperatur, $\mathrm{pH}$-Gehalt, sondern auch den organischen Oxygenbedarf des Wassers an. Die Angaben zeigen, daß die jahreszeitlichen Abweichungen der materiellen Konstanten in diesem Höhlensystem nicht deutlich hervortreten. Algen und Bakterien wurden von Bodenproben und kalkigen Bodensätzen isoliert. Insgesamt wurden 39 Algenarten gefunden. Von diesen gehören 13 zu den Cyanophyten, 22 zu den Chlorophyten und 7 zur Klasse der Chrysophyta-Baccillariophyceae. 38 heterotrophe und 7 autotrophe Bakterien wurden isoliert. Der dünne Film der oberen Wasserflächen enthielt außer den Kieselalgen mehrere Flagellaten und einige Ostracoden, wobei einige mit den Bakterien und Algen assoziierende Protozoen in den weichen kalkigen Ablagerungen gefunden wurden.

1) Several different species showing differing pigmentation. 


\section{ACKNOWLEDGEMENTS}

The author wishes to thank Dr. Kathryn Benson-Evans and also members of the South Wales Caving Club for the assistance she has received in the course of this work.

\section{REFERENGES}

Breed, R. S., Murray, E. G. D., and Hitchens, P. A. (1948) - Bergey's Manual of Determinative Bacteriology, 6th ed. Williams and Wilkins Co., Baltimore.

Breed, R. S., Murray, E. G. D., and Smith, N. R. (1957) - Bergey's Manual of Determinative Bacteriology, 7th ed. Williams and Wilkins Co., Baltimore.

Culuingford, C. D. H. (1960) - British Caving, 2nd ed. Routledge and P. Kegan, London.

Fritsch, F. E. (1959) - The Structure and Reproduction of the Algae. Univ. Press, Cambridge.

Geiger, R. (1959) - The Climate Near the Ground.

Iwatsuki, O., and Ueno, K. (1959) - Mem. Coll. Sci. Univ. Kyoto Ser. B (Biol.) $26(3): 315$.

Mason-Williams, M. A. (1965) - Paper presented at IV. International Congr. Speleol. Belgrad.

Mason-Williams, M. A., and Benson-Evans, K. (1958) - Cave Res. Group, Great Britain. Pub. No. 8 .

Pascher, A. ed. (1925) - Die Süßwasserflora... G. Fischer, Jena.

Prevot, A. R. (1961) - Traité de systématique bactérienne. Duned, Paris.

Tromвe, F. (1952) - Traité de spéléologie. Payot, Paris.

VAndel, A. (1964) - Biospéléologie. Gauthiers-Villars, Paris. 